\title{
TV talk in PNG: A search for policy in a weak state
}

The reasons for the nation-state's weakness are many, but the course of TV talk over the last 10 years in Papua New Guinea reveals one reason in particular: the sacrifice of long-term state-building to the immediate demands of electoral strategy.

\section{BY ROBERT J. FOSTER}

MY EFFORT to formulate a coherent national communication policy does not imply that no policies in this area exist. The communication system in Papua New Guinea would have evolved over a period of time with ad hoc policy decisions being taken as necessary in the light of political considerations and technological innovations. Whilst there has been laws governing communications activities, policies have not been clearly articulated, but were rooted in tradition and precedent.

- Martin Thompson, Minister for Information and Communication Services, December 1993 (PNG 1993: v).

Television in its various forms is already in Papua New Guinea, but it is in a chaotic and most unsatisfactory state. None of them can be considered or accepted as promoting Papua New Guinea cultural values. Because of lack of adequate television policies by successive governments, a situation has been reached in Papua New Guinea that would not be tolerated in most other countries.

- Brown Sinamoi, Communications Minister, speaking at the Pacific Regional Television Conference in Suva, November 1989 (cited in Stewart et. al. 1993:351).

Television in various forms is already here in Papua New Guinea but it is in a chaotic and most unsatisfactory state. Because of a lack of adequate television development policies by successive Governments, a situation has been reached in Papua New Guinea that just would not be tolerated 


\section{ROBERT J. FOSTER}

in most other countries. The situation has been aggravated by entrepreneurial organisations taking advantage of the lack of policy to build up systems that cannot be readily dismantled. In this policy vacuum, without clear standards applying, literally hundreds of satellite receivers have been installed with cable systems criss-crossing nearly all urban centres, often being unsightly and in some cases plainly hazardous.

- The Report of the Board of Inquiry into Broadcasting (Including Television) in Papua New Guinea, January 1987 (PNG 1987:94).

FROM 1985 to 1994 , all efforts to formulate a national communication policy for Papua New Guinea bore the indelible stamp of commercial interests and/or electoral strategies. I will underscore this claim, which is itself hardly new, by recounting the attempts of two separate Governments of Paias Wingti to take up the issue of media regulation - especially the state's regulation of broadcast television (see Horsfield 1990; Wilson 1993; Thomas 1994). In so doing, I will also identify some of the recurrent themes that shape TV talk in PNG - mostly the talk of politicians, church representatives, local academics and media personnel, but also, here and there, the talk of ordinary citizens. These themes emerge in discussions about program content, on the one hand, and questions of economic and cultural dependency, on the other. My review brings together material from various published and unpublished accounts of television in PNG: newspaper reports, official inquiries, scholarly papers, and so forth. This literature is surprisingly small, given that commercial broadcast television has been operating continuously and on an ever increasing scale in Papua New Guinea since January, 1987. Anthropologists like myself ought to pay close attention to the sad fact that intensive field research on television viewing remains virtually non-existent. My orientation is therefore prospective; I aim to assemble preliminary notes for a historical ethnography of television broadcasting and reception in Papua New Guinea.

\section{Launching broadcast television in PNG: The political context}

Commercial television broadcasting in PNG commenced in January 1987 after six months of public debate, legislative maneuvers and, ultimately, court orders. The noise accompanying its arrival contrasted starkly with the silence surrounding the Somare Government's efforts in 1984 to grant broadcasting licences to foreign commercial companies, efforts "characterised by minimal public debate and apparent irregularities at the level of negotiation" (Stewart et. al. 1993:339). 
Not only was the decision to issue the licences a reversal of previous government inquiries into the feasibility and advisability of television - all of which deemed television a low priority for economic development and desirable, if at all, mainly for educational purposes (see Horsfield 1990 for details) - but the decision was also taken in direct contravention of the recommendations of the Post and Telecommunications (PTC) Department, the local licensing authority. Stewart et. al. (1993: 339) observe that when the Department advised the Government that controls were needed in the form of a broadcasting tribunal, the Department was replaced by an "interdepartmental committee set up especially to make recommendations to cabinet on the introduction of television." (The chronology in the Kalo Report [PNG 1987], however, suggests that the interdepartmental committee was formed in response to a request from PTC to the National Executive Council [NEC] for policy guidelines.) When it too recommended to proceed cautiously and to set up a tribunal, this committee was in turn replaced by "a special state negotiating team" that consisted of the departments of the Prime Minister, Finance and Planning, and the State Solicitor (Ibid.; PNG 1987:96). Accordingly, in November 1984, Cabinet directed Posts and Telecommunications to issue a licence to Niugini Television Network (a joint venture with Newcastle Broadcasting Network, a subsidiary of the Perthbased Parry Corporation).

In the same month, a second company, Media Niugini Pty. Ltd., began showing locally produced videos in the major market places of the National Capital District. The following year, Media Niugini, eventually restructured as a joint venture with Publishing and Broadcasting Ltd., a subsidiary of Kerry Packer's Nine Network Australia, applied to PTC for licenses for television services. Two days before the Somare Government fell in 1988 - and months before the details of its merger with Packer's PBL were finalised and publicised - Media Niugini was granted a licence to begin commercial television broadcasting (Post Courier, 20 November 1985).

The change of government in 1985 (in November, with third no-confidence vote of the year) and the declaration of Paias Wingti as prime minister recast the issue of broadcast television as a matter of public debate. Wingti's disagreement with Somare over the appropriateness of introducing broadcast television to PNG apparently had contributed to Wingti's defection from Pangu Pati in early 1985. Wingti, then Deputy Prime Minister, was not present at the Cabinet meeting in which the decision was taken to license NTN. Subsequently, as leader of the opposition, Wingti alleged in Parliament that "two senior govern- 


\section{ROBERT J. FOSTER}

ment officials regularly conveyed confidential information relating to Cabinet discussions and deliberations to the representatives of Newcastle Broadcasting Network" (Stewart et. al. 1993:340). In addition, allegations were made that Sir Ebia Olewale, former Deputy Prime Minister and a friend of Somare's, had been given a 10 per cent share of NTN in order to ease the new company's passage through Cabinet (Stewart et. al 1993:340; Horsfield 1990: 158). Horsfield (1990:158) concludes that these allegations "added to the problems of a government already in a crisis of corruption allegations, and therefore the television issue was a contributing factor in bringing the Somare government down."

In January 1986, Wingti's Communications Minister, Gabriel Ramoi, told the Post-Courier that "Television should only become a priority area when it can be used to develop a national and cultural consciousness. This can only be done if the State is involved in control over the medium either as owner or in the area of legislative control" (Post-Courier, 13 January 1986). In February, the Government announced an inquiry into broadcasting, both radio and television, that would provide the basis for making official media policy. As a result, the licences of NTN and Media Niugini were renewed in March only until November, by which time the result of the inquiry would be known (PNG 1994:2; but an ad for NTN from 1986 asserts that PTC renewed NTN's licence for one year on 30 May1986 [Times of PNG, 18 July 1986]). The NEC established the membership of the Board of Inquiry into Broadcasting and its Terms of Reference in July (PNG 1987: 1). At the same time, Wingti requested NTN not to start broadcasting on its planned date of July 18 , but instead to wait until the outcome of the inquiry was known. NTN refused, took the Government to court, and thereby precipitated two separate legislative attempts by the Wingti Government to delay broadcast television (a strategy to which Wingti had resorted the year before as leader of the opposition). Both attempts were declared invalid by the courts, paving the way for NTN to begin broadcasting in January 1987, the month in which the Board of Inquiry presented its findings.

Media Niugini, by then renamed EM TV (Tok Pisin for "It's TV"), began broadcasting six months later in July. At the time, its ownership was announced as 25 per cent Peter Sam, a PNG lawyer; 25 per cent Alun Beck, a New Zealander who ran a video production company in PNG; and 50 per cent Bond Media, owned by Australian businessman Alan Bond, who had acquired Packer's Publishing and Broadcasting Ltd. when he bought out the Nine Network. By the end of 1989, Bond Media had increased its share of EM TV to 90 per cent 55 PACIFIC JOURNALISM REVIEW 5:1 1999 
(Dorney 1990:238). Today, EM TV is the only station broadcasting in PNG (NTN folded after one year of operations due to Kevin Parry's financial troubles). Through its parent company PBL Pacific Television Pty. Ltd., it is 100 per cent owned by the Nine Network Australia, which is itself back in the hands of media mogul Kerry Packer. According to a 1994 report, "the station employs around 70 Papua New Guineans and does produce some of its own material, though only around 12 per cent of total broadcast time" (PNG 1994:3). EM TV has gradually expanded its broadcasting from Port Moresby, first to other provincial capitals via terrestrial broadcast, then to the whole country via the Indonesian Palapa B2P satellite and, more recently, via the Russian Gorizont satellite. By the station's own current estimates, EM TV is now available to approximately 1.7 to 2 million Papua New Guineans.

\section{Debating TV in 1985-86: Positions}

During the course of events that I have just traced, numerous individuals and agencies - politicians, journalists, church representatives, and the television

\section{Do you want to work in the media?}

\section{investigate}

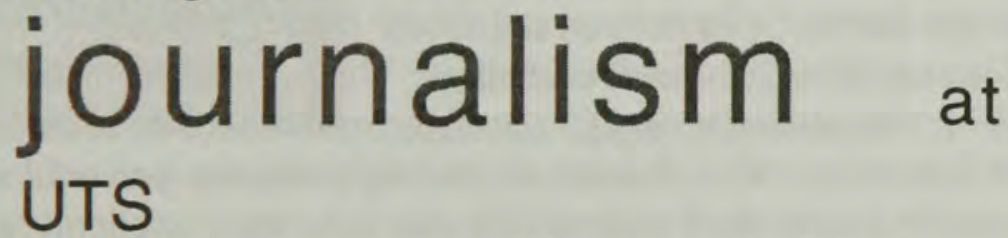

Leading Australia in postgraduate journalism education

On offer in 1999

- Master of Arts in Journalism

- Graduate Diploma in Communication (Journalism)

- Graduate Certificate in Journalism

With streams in print, radio, television and internet journalism including

- Industry placements

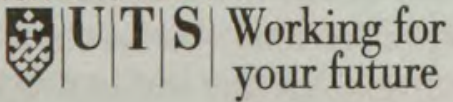




\section{ROBERT J. FOSTER}

companies themselves - staked out various positions on the issue of television in PNG. Their statements, several of which I adduce here, define themes that have shaped and continue to shape TV talk in PNG.

Paias Wingti:In August of 1986, Prime Minister Paias Wingti published a commentary in the weekly Times of Papua New Guinea under the heading "TV must be used to serve the nation" (Wingti 1986). The commentary expresses his opposition to the introduction of broadcast television in PNG, but progressively narrows that opposition to the introduction now of television with foreign programmes. Wingti's rhetoric deploys a number of interrelated oppositions and a heavy emphasis on "our cultures" that pervade TV talk in PNG:

Rural Majority/Urban Minority: Wingti contrasts the interests of the few with those of the many, that is, the interests of a "few powerful and vocal people" with those of the masses or THE people. Wingti contends that a few people, implicitly urbanites, are out to confuse or mislead the people in general, and that his leadership, which stands for "the silent rural majority," is determined to stop them.

Foreign/National: The powerful minority, Wingti suggests, consists of "a group of non-citizens and a few Papua New Guineans, who have a vested interest in television broadcasting." This "handful of Papua New Guineans" is particularly loathsome inasmuch as they are cultural traitors who "seem to have a contempt for their own culture, and favour foreign things."

Material Gain/Cultural Preservation: Wingti contrasts "passing material gain" with "our ancient heritage," claiming that the sacrifice of the latter for the former is at stake. This contrast might imply that the powerful minority is motivated by greed, but it addresses another issue more explicitly, namely, the issue of economic development: "There are people who claim that by our failing to introduce television now, some jobs will be lost, that people will be unemployed. It is a sad fact that some jobs in television may be lost. But what are these few jobs lost to be compared to the loss of our culture, our heritage, or way of life. No money can buy back our languages once they are lost, and no jobs or money can replace our cultural heritage once it is destroyed."

Wingti also proposes, as an alternative to television with foreign programs, the use of television as an instrument for creating a national culture based on unity in diversity. In this view, television would function as a way of educating the diverse groups within PNG about each other's traditions: "Before we, as a people of one nation can respect one another, we must know one another's ways. This is not going to happen if foreign programs, and foreign movies become the 58 PACIFIC JOURNALISM REVIEW 5:1 1999 
This opposition contrasts the torpor and escapism of those who 'withdraw ronment and lock their minds on to the magic screen' with the man who lives by the 'sweat of his brow, and the fruit of his labour'.

\section{PAIAS WINGTI, PNG'S} former Prime Minister from their real envi-

only common factor that we experience through watching television." Hence, the opposition between foreign and national is shorthand for both an opposition between material gain and cultural heritage and an opposition between foreign culture and a national culture comprised of diverse local traditions.

Deceptive Images/Honest Work: Wingti deploys one other opposition in his rhetoric which, though somewhat idiosyncratic, is consistent with the Protestant ethics implicit in his material/cultural dualism. This opposition contrasts the torpor and escapism of those who "withdraw from their real environment and lock their minds on to the magic screen" with the man who lives "by the sweat of his brow, and the fruit of his labours, not by viewing the images of another world and another life which can never be his unless he works for it to become real."

Michael Somare: As Wingti attempted to use the legislature to delay NTN's broadcasts, opposition leader Michael Somare stressed that the agreement between NTN and the State was legally binding: NTN was to begin broadcasting within twelve months from September 1985, when the agreement was signed (Times of $P N G, 18$ July 1986). Somare also reaffirmed his support for the introduction of television: "'Mr. Wingti is being emotional about the entire issue,' he said, adding his support for TV's 'communication and educational value'-as original proposer to Cabinet of the NTN submission" (Ibid.). Indeed, Somare was an apparently enthusiastic supporter of introducing broadcast television to PNG once his concerns about costs (see Pacific Islands Monthly 1984) were allayed by the so-called no cost proposals presented by the foreign television entrepreneurs (i.e., proposals to pay all capital costs and to raise revenue through commercial advertising). He is quoted by Stewart et. al. (1993:346) as saying in Parliament in May, 1985 that "The company will be trying out [television] in Port Moresby, Lae, Mt. Hagen and Goroka. I wish they had included Wewak 


\section{ROBERT J. FOSTER}

[center of Somare's own East Sepik electorate] because I would really love it, but they did not."

I have not yet found any single statement by Somare or his Pangu Pati staking out their position on television. Horsfield (1990) suggests that I would be unlikely to find such a statement inasmuch as Somare, and his Pangu Pati, acted mainly out of economic pragmatism rather than on ideological principles. (Of course, after the defection from Pangu of Wingti and other apparent "left nationalists" to form the People's Democratic Movement in 1985, such economic pragmatism was more pronounced (see chapter two of Thompson and MacWilliam 1992).) Hence she speculates that Somare's decision to hasten the introduction of television in 1985 was prompted mainly by electoral concerns (such as giving PNG the gift of television on its tenth anniversary of independence and using television as a means for social control of the pressing law and order problem). Nonetheless, Stewart et. al. (1993: 347) have inferred from transcripts of debates in Parliament five reasons that Somare and then Communications Minister Roy Evara offered as justification for granting a licence to NTN:

1. The service would offer a large amount of programing in education and health issues.

2. The service would steadily increase its level of local content, beginning at 20 per cent.

3. Ownership of the network would be majority Papua New Guinea.

4. The service would be introduced at no cost to the government. (But see Horsfield 1990:157 about the agreement of the government to buy the necessary transponders and lease them to NTN.)

5. "Television is already in Papua New Guinea" in the form of cable, video, and satellite; a broadcast service, however, would be regulated in contrast with these other services. (The latter implication is not demonstrated by Stewart et. al.; it might be the case that Somare implied, like NTN itself [see below], that television was already in PNG, but only available to a privileged minority.)

It is perhaps reflective of their different orientations to post-colonialism that unlike Wingti, Somare gave no prominence to the issue of custom or tradition in talking about TV in PNG. For Somare, the main issue appeared to have been one of attracting foreign investment, not of cultural autonomy (see Horsfield 1990 for discussion of these two different orientations).

Gabriel Ramoi: Gabriel Ramoi, Minister for Communications in Wingti's 
cabinet, authored a Government announcement that ran in the Times of Papua New Guinea in August 1986 (Ramoi, 1986). Not surprisingly, Ramoi reiterated many of the points made in Wingti's commentary, juxtaposing the interests of the majority against those of the "privileged few" and even going so far as to characterise Somare, "our own Father of Independence," as "a mouthpiece for foreign interests in the country." In particular, Ramoi emphasised the contrast between the relatively affluent urban minority and the poorer rural majority:

... while we can project that a fee of K50 for say 200,000 sets would yield a revenue of $\mathrm{K} 10$ million per year, it is only the urban population that can afford to pay such a licence fee and it is not at all clear that they would be willing to subsidise programing aimed at the interests of the rural sector. We must not forget that more than 85 per cent of the population live in the rural area and have very limited incomes. This means that they will not be able to pay a licence fee nor will they be buying a television set.

Ramoi's concern for the rural majority, however, focused less on the threat television might pose to "ancient heritages" and more on the capacity of the rural population to become involved in local programing. Ramoi's specific suggestion in this regard was to delay the advent of broadcast television until the expertise needed for producing local programing was acquired through the making of "participative videos" documenting successful development projects in small rural communities. In other words, Ramoi's objection to foreign programs was made less on the grounds of their content and more on the grounds that they precluded the development of a television industry that involved all Papua New Guineans: "Many of the proposals so far have been very vague when it comes to questions about local programme production, about adequate training for staff in terms of community life in PNG, about appropriate language use, and about a balanced spread of viewing opportunities among the population as a whole." In sum, Ramoi asserted that it is "the responsibility of the Government to ensure that mass broadcasting like television promotes national development objectives." The alternative to such control, Ramoi said, was to let television broadcasting "go its own way aimlessly spreading commercial and cultural exploration [sic? exploitation?]."

Niugini Television Network: On the day that NTN had planned to begin broadcasting, the network ran a two-page ad in the Times of Papua New Guinea (18 July 1986). The ad described "the situation" from the point of view of NTN, noting that an estimated 20,000 television sets were already in PNG and over 250 hours of television via cable and satellite were available to viewers in Port 


\section{ROBERT J. FOSTER}

Moresby alone. The ad then claimed that "Parliament House has two satellite dishes for television reception wired to the amenities room and the members bar" and that "several cabinet ministers are receiving television at their homes via cable or satellite." By implication, then, television was an amenity currently enjoyed by those politicians who sought to prevent the less privileged from enjoying ("free") broadcast television. That is, the network, like Wingti and Ramoi, rhetorically deployed an opposition between the elite and the masses, but in order to challenge rather than support the claim that the government served the interests of the majority.

The reproduced remarks of Sir Ebia Olewale, chairman of NTN, developed the implications of NTN's description of "the situation." Sir Ebia's words were reported to express "his sadness and concern for the right of individuals affected by the Government's abrupt intervention into Broadcast Television." Sir Ebia's comments are worth quoting in their entirety:

There are many Papua New Guinea people who have joined the industry, who wish to learn and have a contribution. The Government's decision sweeps them aside. This is a democracy. The rights of the individual must be respected, as well as the interests of the State. There are the wishes of the people to consider, as well as the support of all the eminent men and women who have spoken in favour of Television. The culture of Papua New Guinea will not be destroyed by Television. It will bring the Nation together. The people will learn about each other's customs. Ten years ago there were people who said we were not ready for Independence. Today they can be seen to be wrong. This Nation is now ready for Television. It is what the people want.

The ad concludes with the salutation, "Papua New Guinea, We're With You," and the NTN logo, thereby raising the questions: who is and who speaks for Papua New Guinea-for "the people"? Sir Ebia's words address the issue of national culture, but they effectively focus the debate on the issue of the rights of the individual and the role of the state in a democratic society. They plead, in other words, for the entitlements of consumer-citizenship: equal opportunity to enjoy the consumption of freely accessible commodities. The denial of such consumption is attributed to a state that is either overstepping its legitimate authority or acting out of misplaced paternalism. Sir Ebia thus conjures the specter of censorship and loss of freedom, a spectre that was to hover closely above subsequent TV talk in PNG.

Media Niugini: On July 11, 1986, Media Niugini expanded its operation 
from the markets of Port Moresby to a "nationwide network" that included markets in Lae, Mt. Hagen, Ok Tedi and Rabaul, as well as sports and social clubs, hostels and educational establishments throughout PNG. This expansion marked a new stage in the effort "to educate and acclimatise PNG audiences for the arrival of broadcast television." The company, which described itself as "PNG's original community TV service" (NCTV or Nationwide Community TV), announced its expansion in inserts to the Times of Papua New Guinea. The inserts - designed to attract advertisers - marketed the company's effort in terms of the same rural/urban, "grass roots"/affluent oppositions deployed by Wingti and Ramoi, but to very different ends. For example, the insert described the "unique concept" of "community television": "The concept of bringing television to the grass roots audiences in PNG is of course contrary to the usual format for introduction of television services, and it brings added responsibility to the programers. Under normal circumstances with broadcast Television the first audiences to receive television would be the more affluent sections of the community. With NCTV reaching directly down to the broad base of the community it is communicating with the audience that supports the largest segment of the retail markets from which the retail trade derives the major part of its income." NCTV stressed that marketplace viewers included not only urban residents, but also vendors who travel from rural areas: "These people will not only carry the news back to the villages, but having sold their produce, will carry back bulk purchases of food and other supplies." In short, NCTV promoted the image of a nationwide consumer-democracy in which all citizens would have access to the images and commodities purveyed by television. These images would include not only entertainment, but also community service announcements: "As part of NCTV's commitment to community service the programmes also carry, free of charge, public service and community announcements for charities and service clubs. There will also be Government sponsored educational programmes such as the recently completed agricultural film on the prevention of coffee rust." In this way, Media Niugini, represented itself as serving the interests of the majority-including the rural majority - by not only making the amenity of television widely available, but also contributing responsibly to the Government's agenda of national development.

Three Contributors to the Times of PNG: A quick flip through the July and August 1986 pages of the Times of Papua New Guinea reveals support for 


\section{ROBERT J. FOSTER}

Wingti's position coming from a variety of sources. I simply note a few of those sources here, making no claim that they are either typical or representative of any "elite" perspective let alone larger public opinion.

Ray Anere, political columnist for the Times and lecturer at UPNG, described a "battle between corporate actors and governments, the latter being the custodians of public interest." Invoking the Eight Aims and the egalitarian ideals of the constitution, Anere endorsed Wingti's attempt at administering television according to national goals and directive principles: "How can any government in PNG administer television broadcast if there is no legislation? In this respect the state would be powerless via-a-vis corporate influence in safeguarding local culture and interests and at the same time do economic justice to the companies if it did not have the backup of legislation?" (Times of PNG, 18 July 1986).

Sheldon Weeks, longtime educational researcher in PNG, doubted the claims for television's educational benefits: "Producing educational programmes for TV when we cannot even revise and produce new ones for radio sounds like a con (a fantasy sold to us by the promoters)." Weeks argued that television ought not be a high priority given the country's need for basic infrastructure, and that finances and resources for producing local educational programmes were unlikely to be made available. (Times of PNG, 22 August 1986)

Fr. Dennis Rochford, MSC, expressed what might be taken to be the Churches' view of the matter, claiming that the "major worry" was the lack of legislation to enforce broadcasting quotas and standards: "There are more important values at risk in this issue. As Christians we are more concerned for persons and their development than we are for accommodating the entertainment of a minority - even if there are 20,000 television receivers in PNG! It would seem essential, against a background of cultural alienation, manipulation and exploitation to institute administrative bodies and policies capable of effectively monitoring and controlling the standards and quotas of foreign media groups." Much like Wingti, Rochford posed a choice between commercial profit, on the one hand, and the interests of people, on the other. (Times of $P N G, 22$ August 1986)

\section{The Kalo Report: Program content and public opinion}

The Report of the Board of Inquiry into Broadcasting (Including Television) (PNG 1987), chaired by Sir Kwamalo Kalo, presented findings that, not

\section{PACIFIC JOURNALISM REVIEW 5:1 1999}


surprisingly, echoed the views and concerns of Wingti and Ramoi. For example, of the 17 terms of reference that it was charged to consider, the Board concluded that Term of Reference Number 13, reproduced here, "indicates the fundamental objectives of broadcasting in our nation" (PNG 1987:10):

(13) The reflection in broadcasting and television of the multi-cultural nature of PNG society; the recognition of regional, sectional and minority interests in the structure of broadcasting and television in programme design, including provision of opportunities for access to broadcasting and television, and further including the recruitment and training of staff of television operators.

Nevertheless, the report documents that the many people interviewed by the Board - a total of 1338 persons and organizations consulted through written submissions and public hearings in eight major towns - talked about TV in other terms. Specifically, the report claims that "during the course of the Inquiry, the Board heard in virtually every place visited, expressions of deep concern about the effects of foreign programmes on our society" (PNG 1987: 100). And, in fact, the report devotes more attention to its recommendations on program content (Terms of Reference 15, 16 and 17) than it does to the "fundamental" Term 13. What is at stake here, then, is not only or even mainly a concern with foreign imports as a threat to local cultures, but more urgently a concern for the behavioral effects of viewing violent and obscene foreign programs. Given that the Board conducted its inquiry against a growing sense of lawlessness and disorder in urban PNG - and the actual declaration of a State of Emergency in Port Moresby in 1985 - this response is not extraordinary. I emphasise it for two reasons.

First, the Kalo report itself suggests that the issue of regulating violence on television exposed a rift between NTN and Media Niugini, on the one hand, and the witnesses that came before the Board:

Both companies treated the violent program issue on the basis that selfregulation, as prevails in Australia, should be accepted in Papua New Guinea. Virtually all other witnesses to appear before the Board disagreed with the above and demanded that proper and timely controls on program content be introduced (PNG 1987:104).

It was precisely these observations that precede one of the Board's most important and controversial recommendations, namely, that strict program regulation be a function assumed by a Broadcasting Tribunal established through government subsidy and funds from commercial broadcasting services 


\section{ROBERT J. FOSTER}

(PNG 1987: 100; see also p. 28).

Second, the issue of how viewing violent programmes might affect audiences, especially children and teenagers, seems to preoccupy the category of people whom it might please to refer to themselves as "grass roots" - that is, people who are neither politicians nor bureaucrats nor university lecturers. Put otherwise, concern over the harmful effects of viewing seems to eclipse issues of economic development and cultural autonomy for at least some of the people talking about TV in PNG. Here I tread cautiously, wary not to presume or promote the same romantic vision of "the people" that Wingti and Ramoi sometimes conjured in their evocations of "the silent rural majority." I do not have access to transcripts of the actual public hearings held by the Board of Inquiry, and I am well aware of the strong representation of Christian church interests on the Board. I simply note that the following views were attributed by the Kalo Report to a large proportion of the diverse group of people interviewed by the Board:

The importance of religion to Papua New Guineans led many witnesses before the Board to urge an increase in religious broadcasts (PNG 1987:52).

In the course of this Inquiry, the Board heard numerous submissions from a wide range of people and organisations, expressing deep concern over the amount of violence presented in television, and more particularly on pre-recorded video tapes (PNG 1987:59, original emphasis).

As indicated in subsequent paragraphs the Board was inundated with pleas of deep concern from communities throughout the country over the uncontrolled and unremitting trade in violent, pornographic and sexist video tapes (PNG 1987:65).

Is there any other basis, besides my own intuition, on which to accept these generalizations as plausible?

It would be easy, and probably correct, to assume that the Board of Inquiry's findings articulate a style of TV talk inflected by the world view of Christian churches in PNG. For instance, Catalyst, the organ of the Melanesian Institute, a Christian pastoral outfit based in Goroka, published two articles critical of EM TV's programme content (Boorer 1990, reprinted from the Times of PNG; Gemo 1991). These articles linked violent programs to the use of shotguns in tribal fights and want-inducing advertisements to an increase in crime in towns and cities. Likewise, Sr. Maria Burke's (then director of the institute) contribution to the 1986 Waigani Seminar implicated television viewing as a cause of rascalism among youth. It stated furthermore that:

66 PACIFIC JOURNALISM REVIEW 5:1 1999 
Television violence is dangerous in that it portrays an unacceptable social vice as being normal. Papua New Guinea village dwellers are not sophisticated in their approach to Western society and could easily be deceived into thinking that violence was an acceptable part of Western culture (1989:149).

There is some evidence, however, that the concerns expressed in the report and in Catalyst reflected more widely held anxieties about television. (This perhaps should not come as a total surprise given the strong Christian values of many Papua New Guineans.) An analysis of essays written by 77 teachers as part of the 1986 admissions test to UPNG's in-service BEd program revealed that 75 per cent of the candidates felt television would have mostly negative social effects:

People would become addicted to viewing; children would ignore parents; the influence of the Church would be significantly reduced to the detriment of village life; programs showing sex, violence and other undesirable behaviour would cause social aisruption and teach rascalism; people would stop visiting each other; people would head for the urban attractions of towns (Boorer and Kiruhia 1989:157, emphasis added).

Respondents also made a connection between advertising and crime:

There was a general feeling that inappropriate material demands would be set up either by programs or by advertisements. Once these could not be satisfied by legitimate means a proportion of the population would inevitably turn to crime to do so. . . (Boorer and Kiruhia 1989:158).

Similarly, the essays frequently expressed concern about the potential for intensifying social inequality between those who could afford television sets and those who could not.

The results of the only ethnographic study of television viewing in PNG known to me also confirms the outlook of the Kalo Report (PNG 1994). Carried out by the Policy and Research Branch of the Department of Information and Communication in June, 1994, this study consisted of interviews with 20 families (five of whom had cable/satellite TV), two women's groups, and one men's group from Hanuabada and Pari villages near Port Moresby. (It should be pointed out that both villages are described as "Christian villages" and "very committed to their churches"; moreover, the interviewing team initially established contact with the villages through their United Church pastors; in addition, Rev. Oria Gemo was at the time Asst. Sctry. (Policy and Research) of the Dept. of Information and Communication (see Gemo 1994).) Interestingly, the study notes that "we had a hard time explaining that we were from a government 
ROBERT J. FOSTER

department and not from EM TV and that we were therefore not in a position to change EM TV's programming, which was one of the major concerns expressed" (PNG 1994:5). Yet despite this and other admitted methodological limitations, the study usefully describes how and when villagers watched TV as well as what programs they watched.

With regard to programs, the study claims that:

Movies were also extremely popular an so was the new, locally produced, Christian programme, Sing With joy. The only complaint about Sing With Joy was that it was too short and that it ought not to be interrupted by commercials. A number of families were outright offended by commercials appearing in a Christian programme (PNG 1994:6).

The majority of families expressed a desire for more Christian programmes; one elderly man is recorded as saying "I do not know why EM TV does not put on Bible programmes" (PNG 1994:7). The majority also expressed a desire for more locally produced programs; indeed, the study is a pointed contradiction to EM TV's claim, reported by Stewart et. al. (1993:356), that "Papua New Guinean audiences prefer to watch overseas programs rather than local productions." But it is the views of the families on the potential effects of TV viewing that seem most in line with those of the Kalo Report:

The general perception was that TV has a very strong effect on people's behaviour. Most families saw the escalated law and order problem in PNG as a direct result of TV and feared the influence of violent movies. An elderly woman said: "I do not like violent movies because they contribute to rascalism, rape and many other law and order related problems."

A young man said: "If people are watching TV, they are learning from TV - instead of learning we are killing. People do what they see, steal, kill, etc." (PNG 1994:10).

Not surprisingly, then, most families were supportive of the Censorship Board, some criticising it for not being strict enough. Women, in particular, expressed concern over the difficulty of censoring what children watch, especially given that large groups of people, including the children of other people, would gather in a particular house to watch TV.

What the Department of Information and Communication study reveals, among other things, is that TV talk in the villages of PNG is not wholly unlike TV talk in the towns and cities of the United States. People expressed dissatisfaction with the amount of advertising and anxiety over the harmful effects on children of viewing violent programs. Of course, there are differ68 PACIFIC JOURNALISM REVIEW 5:1 1999 
ences, and more complex issues about social relations and identities, consumerism, modernity and so forth that only ethnographically intensive studies will be able to elucidate (see, for example, the discussion of Chambri reactions to the popular Pepsi-sponsored music video program, Fizz, in Gewertz and Errington, 1996). Like the report, I can only conclude, somewhat lamely, that more ethnographic research is needed.

\section{The Mass Media Tribunal: Exit Paias Wingti}

The frustrated efforts of the Wingti Government to prevent the unregulated broadcast of commercial TV in PNG culminated in Gabriel Ramoi's announcement in November 1987 of his plans for a mass media tribunal. This tribunal, however, "would licence not just television, but all media - television, radio, the newspapers, magazines, videos and even outdoor advertising" (Dorney 1990:238). The proposed Mass Media Tribunal Bill was, in the end, removed from the Parliamentary agenda before it reached the debating stage (see below). Although the bill presented itself as the direct outcome of the Kalo Report and outlined a philosophy of fundamental media rights, journalists' accounts of the bill tend to highlight three main points:

1. "The Government would empower the tribunal to licence all media organisations. This licence would be renewed every so often after a public inquiry proved each organisation had carried out all the conditions of its licence" (Senge, 1988:21).

2. "The Government would require all foreign control in media firms to be 50 per cent nationalised within 10 years. No one individual or firm - whether foreign or national - could own more than 17 per cent of the Media" (Ibid.). (Dorney 1990:239 summarizes this point differently.)

3. "... the tribunal would have the power to direct a licensee to publish matters that it (the tribunal) or the Minister for Communications deemed to be of national importance; and that the tribunal could direct a licensee not to publish matters that were prohibited by the censor, the tribunal, or the Minister" (Ibid.). Dorney (1990:239) adds that later the determination would lie with the Governor-General.

Reaction to Ramoi's proposed bill seems to have come quickly and forcefully from the print media (whose activities were not the subject of the Kalo Report) and to have focused mainly on point number three, which was widely interpreted as a threat to the freedom of the press (for more detail see Senge 1988; Dorney 1990; Robie 1995a; Layton 1988, 1993). For example, Oseah 


\section{ROBERT J. FOSTER}

Philemon, then a senior journalist and later the editor of the Post-Courier, PNG's largest newspaper, is quoted as saying that:

A government that legislates to control the media is a government that does not want public scrutiny of its decisions. It is a government that does not intend to be accountable for its policies and actions (Senge 1988:22). Philemon's response is particularly significant inasmuch as he had earlier publicly supported the attempts of the Wingti Government to reassess the agreement to begin commercial broadcast television into PNG (Times of PNG, 23 December 1985). Similarly, Leader of the Opposition, Michael Somare, characterised the bill as "dictatorial" and "suppressive," and said that "such a bill contravened section 46 of the Constitution on freedom of expression and was a "trend towards guided democracy"' (Senge 1988:21-22).

Ramoi himself defended the proposal — or, at least, the concept behind the proposal (Ramoi 1988: 9) -in nationalist terms that were consistent with his and Wingti's previous statements on broadcast television. He told Pacific Islands Monthly (February 1988) that:

Newspapers have set the agenda for debate wrongly. The issue for debate is whether or not foreigners should control mass media in PNG. The argument that the Government is trying to control the press is a red herring in this instance because the Government intends to establish a tribunal that will be very independent (see also Ramoi 1989).

(Concerns about foreign ownership were perhaps more applicable to broadcast television than any other media, though it is pertinent to remember that the PostCourier is owned by Rupert Murdoch's News Ltd through one of its many subsidiaries.) Similarly, Ramoi told a public seminar on "Media and Development," hosted by the Institute of National Affairs in February 1988, that:

. the concept of a mass media regulatory body must be seen as a manifestation of our political will, in the face of failed expectations, to determine the destiny of our nation by moulding a national character that can be described as Papua New Guinean as envisaged in the preamble to our Constitution; and not to allow the media to foster false hope and expectation among our people as a result of their pursuit of profits. Secondly, it must be seen as the continuation of a process of distributing "modern wealth" in a more equitable manner-from the control of foreigners and foreign managers to a new class of Papua New Guinean managers and entrepreneurs (Ramoi 1988:9).

Ramoi specifically addressed Somare's criticism, noting the Government's sensitivity to Section 46 of the Constitution and asserting the lawfulness of the 
The print media maintained their firm opposition to the proposed bill right up until the first Parliamentary sitting of 1988 in April, when the bill was scheduled to be introduced. The two TV companies did not join in the press campaign.

Government's attempt to regulate - not restrict - "free speech" (Ramoi 1988:11). He even qualified his own statements somewhat by welcoming foreign investment "in the dynamic sector of the economy such as mining and fishing industries" and restricting the Government's attempt to reduce foreign ownership to "the service sector," of which the mass media were a part.

The print media maintained their firm opposition to the proposed bill right up until the first Parliamentary sitting of 1988 in April, when the bill was scheduled to be introduced (see Horsfield 1990:205). As Horsfield (1990:206) points out, the two television companies did not join in the press campaign against the bill. Indeed, Ramoi (1988:10) claimed in his remarks to the NIA seminar that EM TV "accepts the general terms of the proposed bill" and endorses the concept of a tribunal acting "in the interests of 'a service to Papua New Guinea that is both beneficial to the country and commercially viable in nature." Horsfield speculates that the television companies maintained a low profile at the time because "their interests, where applicable, were being adequately served by the persistent and highly vocal press campaign, and partly because. . both companies were not opposed in principle to the concept of government regulation which recognised the need to protect public interest in the socio-cultural sphere" (1990:206).

In February 1988, PIM reported that "The opposition sees the issue [of the media bill] as a tool to unseat the Wingti Government with a vote of no confidence in the April sitting of parliament" (Senge 1988:22). But despite Wingti's admonition that the debate over the bill had major consequences for the Government, Ramoi continued to attack the media, alleging in the weeks before Parliament was to sit "a major conspiracy to destabilise and remove an elected government from office" (quoted in Dorney 1990:242). The April sitting was aborted after three hours to avoid a vote of no confidence against the Govern- 


\section{ROBERT J. FOSTER}

ment; the media bill was removed by Wingti from the parliamentary agenda. Three months later, when Parliament next met, the Wingti Government was replaced by the Namaliu Government in a parliamentary vote. The Namaliu Government promised, among other things, a more favorable social and economic climate for foreign investment in PNG.

\section{The return and re-exit of Wingti}

I am uncertain at this point if the Namaliu Government initiated any new policy efforts in the area of broadcast television or mass media in general (but I note in this regard how Brown Sinamoi repeated the findings of the Kalo Report almost verbatim in the 1989 speech cited at the beginning of this article). I am also uncertain about the overall volume and shape of TV talk during the years of the Namaliu Government (1988-1992). These are topics for further research.

The Department of Information and Communication - abolished since Independence in 1975 - was reestablished in August 1992 by the new Wingti Government formed after the June elections. In November, "the Secretary of the Department was instructed to start the process of policy formulation" (PNG 1993:v). A fourteen member advisory committee was established and a public awareness campaign - including a National Communications Policy Seminar (Philpott 1993) - was begun by Communications Minister Martin Thompson in early 1993. According to Robie (1995a:91; see also the preamble of the National Policy on Information and Communication), the committee was asked to apply the following "fundamental principles":

1. Everybody has a right to be 'dynamically involved' in the processes of development.

2. Everybody should have the right to access to information and communication.

3. Access to information and communication should be equitable as possible.

4. A national communication system should be 'comprehensive, varied and flexible enough' to meet the demands of all.

5. Communication processes should be 'free from domination by individuals or groups, whether foreign or local, state or private,' and should respect everybody's interests.

6. Communication processes should contribute wherever possible to: (a) development of the whole person; (b) national identity And unity; (c) cultural preservation and enrichment; (d) democratic political processes; (e) self-reliance; and ( $f$ ) environmental protection. 
7. Some degree of supervision by the Government is necessary to protect human rights and achieve national goals.

The reaction to this turn of events on the part of the print media was again one of trepidation, particularly over Thompson's call for a Journalists Registration Board (see Robie 1995a: $91 \mathrm{ff}$ for details). It apparently did not help matters that the proposal for such a board was mooted " after a team from PNG's Department of Information and Communication returned from a fact-finding visit to Indonesia, Malaysia, and Singapore" (Robie 1995a:93). But when the final policy (PNG 1993) was presented in Parliament in February, 1994, it contained nothing about a registration board and little in the way of the harsh measures that many journalists, at least, feared. In fact, the National Policy on Information and Communications explicitly states in its Preamble that: "We acknowledge that communication is a right equal with all other rights. It includes the right to inform and to be informed, the right to freedom of expression, and the right to freedom of information and assembly, and the right to communication opportunities. It is subject only to the rights of others under the National Constitution" (PNG 1993:7). While the policy thus broadly addresses many of the same concerns as both the Kalo Report and Ramoi's Mass Media Tribunal Bill, it does so in a way that poses no crude threat to constitutional guarantees.

In retrospect, however, the fears of the print media - I am unaware of the reactions of broadcast media, including EM TV, as well as of other segments of the PNG citizenry - seem more than warranted. First of all, the attempt to formulate a national policy on communications and information came at a time when the Wingti Government was to all appearances moving in the direction of authoritarianism. Bill Standish (1994:66) notes that:

Measures recently sought by the Wingti government have gone much further than those of its predecessor, and include three major bills: one to reverse the onus of proof in certain types of criminal case; one to allow the courts to deny bail to a large category of accused persons; and one to create a system of national registration and personal identity cards. The 1993 legislation added to concern among some in political circles that the Wingti government was becoming increasingly authoritarian, seeking to gather all state power into the executive and use it to exclude any opposition at national or provincial levels. Such concerns were again expressed after Mr. Wingti's resignation and instant re-election tactic of 24 September 1993. Designed to extend his tenure of office, this move was described by his political opponents ... as a 'constitutional coup', the act of a 'dictator' seeking a 'guided democracy' and lifetime rule. 


\section{ROBERT J. FOSTER}

Secondly, the actions of both Minister Thompson and Wingti himself with respect to the mass media grossly contradicted the stated ideals of the National Policy. In April 1994, for example, Thompson banned the National Broadcasting Commission from reporting on a conference of premiers from the Islands region who were discussing draft legislation for the creation of a new "Federated Melanesian Republic." Invoking the principle of national unity, Thompson explained: ". . . that whilst it is our duty to provide balanced, objective, and impartial broadcasting service, it is paramount that such services should reflect our drive for national unity and that we should take extreme care in broadcasting material that could inflame racial or sectional feeling" (quoted in Hiambohn 1994:192).

Perhaps more incredible, at least symbolically so, was the support that Wingti gave to the launching of a the new daily newspaper, The National, in late 1993. Despite its name, and its promotional slogan: "The National speaks for PNG"- The National is majority owned by a subsidiary company of the huge Malaysian timber group, Rimbunan Hijau, the single largest forestry development company in Papua New Guinea (see Robie 1995b:31). Media critics and opposition politicians were quick to point out the manifest conflict of interest, some challenging Wingti to declare any interest of his own in the paper. Wingti commented at the launch of the paper that the country would benefit from the competition between two dailies and he noted that freedom of expression was rightly guaranteed by the constitution and that everyone should fight to uphold this freedom (Times of $P N G, 11$ November 1993).

Robie (1995a:94) reports that there was some initial criticism and public debate about the NPIC soon after it was tabled in Parliament. Hiambohn (1995:196) quotes former Attorney-General and prominent intellectual Bernard Narokobi as dismissing NPIC in parliamentary debate as a policy of "misinformation and non-communication": "I am not going to burn this report because it does not have any substance. . . It has simply been written by fools." But scrutiny of the policy appeared to have faded before the August declaration of Wingti's resignation-re-election tactic as unconstitutional (see, however, the discussion in the inaugural issue of Pacific Journalism Review). That declaration resulted in the election of Sir Julius Chan as Prime Minister in a new coalition government.

\section{Conclusion: The search for policy in a weak state}

In concluding, I can do no better than to take up some of the conclusions 74 PACIFIC JOURNALISM REVIEW 5:1 1999 
presented by Horsfield (1990) in her most useful MA thesis on the introduction of broadcast television into PNG. Writing about the ultimate failure of the Mass Media Bill in 1988, Horsfield comments:

The failure of this most recent attempt to apply some form of government control to the so-called 'culture industries' reflects the continued inability of the Papua New Guinea government to assert its will in matters of policy - especially in policy where foreign investment is involved, as was the case with the largely foreign-owned Papua New Guinea press (1990:168).

In Horsfield's view, the failure of the PNG government to implement policy is not only an index of its dependent position in the global capitalist economy. It is also an index of the weakness - or softness, or broken-backedness (see Standish 1994) - of the PNG state.

The reasons for the nation-state's weakness are many, but the course of TV talk over the last ten years reveals one reason in particular: the sacrifice of long term state-building - of policy formulation, for instance - to the immediate demands of electoral strategy (see Strathern 1993). This situation has produced large gaps between public service and politics, between the talk of politicians about the media, especially broadcast television, and their actions. Thus Somare's decision to hurry the introduction of broadcast television ignored all the official findings of every previous inquiry into the matter. Electoral considerations of delivering economic development seemed paramount. Wingti's rise to political prominence was aided by his opportunity to expose the gap between Somare's talk about TV's "educational" role and the grim realities of programing on NTN. But Wingti's own attempts to set policy for the media drifted increasingly far away from his talk about agrarian democracy, constitutionally guaranteed rights, and the importance of local ownership. Given the famous instability of the political process in PNG, policy formation, let alone implementation, is a reflex of more urgent efforts to avoid or survive changes of government. No doubt the same observation could be made regarding state policies on logging and mining industries, industries like media in which the circuits of capital are rarely national.

But this observation perhaps directs attention away from diagnoses of weak states to the "tension between the national and international character of the state" exacerbated by "the centralisation and concentration of capital" in media (Scott MacWilliam, personal communication). Witness in this regard the struggles of "strong states" such as Australia in formulating a national policy on 


\section{ROBERT J. FOSTER}

media ownership (or the history of contests and qualifications surrounding the PNG Commercial Advertising Act, passed in 1985 to nationalize ownership and control of the advertising industry). The observation also directs attention to the question of how "strong societies," for which PNG is justly famous, might effectively resist and engage both the national state and transnational capital. Anthropologists have written accounts of such engagements with respect to logging and mining projects in which local landowners have been able to act collectively and efficacioulsy (see, e.g., Biersack 1995). With respect to broadcast television, however, the much touted strength of PNG's indigenous societies to determine their futures appears to be severely compromised-if not by a weak national state, then by the agents and agencies (both domestic and foreign) of a strong global market.

\section{Acknowledgments}

I thank Scott MacWilliam for his incisive comments on this article and Suzanna Layton for generously sharing her unpublished work and providing me with a draft copy of the aborted Media Tribunal Bill. I also thank John Taylor for his comments on an earlier version of this article. The research on which this article is based was supported by grants from the Australian-American Educational Foundation, the American Council of Learned Societies, the Spencer Foundation and the University of Rochester. The data presented, the statements made, and the views expressed are solely the responsibility of the author.

\section{References:}

Biersack, Aletta (1995), "Introduction: The Huli, Duna, and Ipili Peoples Yesterday and Today." In Papuan Borderlands: Huli, Duna, and Ipili Perspectives on the Papua New Guinea Highlands, edited by Aletta Biersack, 1-54. Ann Arbor: University of Michigan Press.

Boorer, David (1990), "TV and Your Children: TV in PNG-The First Four Years". Catalyst 20:389-391. (First published in The Times of PNG).

Boorer, David and John Kiruhia (1989), "Television in Papua New Guinea". In The Ethics of Development: Language, Communication and Power, edited by Charmian Thirlwall and Philip Hughes, 153-160. Papers from the 17th Waigani Seminar, 7-12 September, 1986. Port Moresby: University of Papua New Guinea Press.

Burke, Sister Maria (1989), "Effects of Television on Melanesian Culture". In The Ethics of Development: Language, Communication and Power, edited by Charmian Thirlwall and Philip Hughes, 145-152. 17th Waigani Seminar, 7-12 September, 1986. Port Moresby: University of Papua New Guinea Press. 
Dorney, Sean (1990), Papua New Guinea: People, Politics and History Since 1975. Sydney: Random House Australia.

Gemo, Oria (1991), "The Impact of Communication Media". Catalyst 21:191-198.

- (1994) "PNG's New Information Order (In Waiting)". Pacific Journalism Review 1(1):38-47.

Gewertz, Deborah and Frederick Errington (1996), "On Piety and PepsiCo in a Papua New Guinea 'Modernity', American Ethnologist 23:476-493.

Hiambohn, Wally (1995), "Secessionist Talk and a Radio Ban". In Nius Bilong Pasifik: Mass Media in the Pacific, edited by David Robie, 191-197. Port Moresby: University of Papua New Guinea Press.

Horsfield, Julianne (1990), "The Introduction of Broadcast Television into Papua New Guinea: A Case Study in the Sociology of Mass Communication". Unpublished MA thesis, La Trobe University, Melbourne.

Layton, Suzanna (1988), "The Mass Media Tribunal Bill: Media and Political Participation in Papua New Guinea". Unpublished Typescript.

- (1993), "Media Freedom in the Pacific Islands: A Comparative Analysis of Eight Nations and Territories". Unpublished PhD thesis, Department of Journalism, University of Queensland, Brisbane.

Pacific Islands Monthly (1984), "PNG Looking Again at TV?" April, p. 28.

Papua New Guinea (1987), "The Report of the Board of Inquiry into Broadcasting (Including Television) in Papua New Guinea". Port Moresby: Government Printing Office.

- (1993), "National Policy on Information and Communication of Papua New Guinea". Division of Policy and Research, Department of Information and Communication. Port Moresby: Government Printing Office.

- (1994), "TV Impact Study on Pari and Hanuabada Villages, Papua New Guinea". Division of Policy and Research, Department of Information and Communication. Port Moresby: K. Kaiah, Acting Government Printer.

Philpott, Malcolm (1993), "Papua New Guinea: Developing a National Communication Policy". Media Information Australia, No. 68:57-62.

Robie, David (1995a), "An Identity Crisis for Pacific Media". In Nius Bilong Pasifik: Mass Media in the Pacific, edited by David Robie, 79-95. Port Moresby: University of Papua New Guinea Press.

- (1995b), "Ownership and Control in the Pacific". In Nius Bilong Pasifik: Mass Media in the Pacific, edited by David Robie, 5-15. Port Moresby: University of Papua New Guinea Press.

Ramoi, Gabriel (1986), "How to Benefit from TV. . . and Avoid Harmful Side Effects". (Government Announcement), 15 August, The Times of Papua New Guinea.

- (1988), "Concepts of the Mass Media Tribunal". In I.N.A. Seminar Development and the Media, edited by John Millett, 8-12. Port Moresby: Institute of National 


\section{ROBERT J. FOSTER}

Affairs.

- (1989), Interviewed by Suzanna Layton. July 26, Port Moresby.

Senge, Frank (1988), "Shackling the Media". Pacific Islands Monthly, February, 21-22.

Standish, Bill (1994), "Papua New Guinea: The Search for Security in a Weak State". In Papua New Guinea: Issues for Australian Security Planners, edited by Alan Thompson, 51-97. Canberra: Australian Defence Studies Centre.

Stewart, Julianne, Bruce Horsfield and Peter Cook (1993), "Television and Dependency: A Case Study of Policy Making in Fiji and Papua New Guinea". The Contemporary Pacific 5:333-363.

Strathern, Andrew (1993), "Violence and Political Change in Papua New Guinea". Pacific Studies 16:41-60.

Thomas, Amos (1994), "Broadcast Policy versus Commercial Imperative: Television Programming in Papua New Guinea." Media Asia 21:7-13.

Thompson, Herb and Scott MacWilliam (1992), "The Political Economy of Papua New Guinea: Critical Essays." Manila: Journal of Contemporary Asia Publishers.

Wilson, Helen (1993), "Television in Papua New Guinea: Policy Challenges in the Satellite Age”. Media Information Australia, No. 68:50-56.

Wingti, Paias (1986), "TV Must Be Used to Serve the Nation." The Times of Papua New Guinea, 8 August.

$\square$ Robert J. Foster is Associate Professor in the Department of Anthropology, University of Rochester. This paper was prepared under the original title "TV Talk in PNG: The Search for Policy in a Weak State".

Email: RFTR@DBV.CC.ROCHESTER.EDU 